\title{
Technology Foresight About R\&D Projects Selection; Application of SWARA Method at the Policy Making Level
}

\author{
Sarfaraz Hashemkhani Zolfani ${ }^{1}$, Jalil Salimi ${ }^{1}$, Reza Maknoon${ }^{1}$, Kildiene Simona ${ }^{2}$ \\ ${ }^{1}$ Amirkabir University of Technology \\ P.O. Box 1585-4413, Tehran, Iran \\ E-mail.sa.hashemkhani@gmail.com,jalil.salimi@gmail.com,rmaknoon@yahoo.com
}

${ }^{2}$ Vilnius Gediminas Technical University

Sauletekio av. 11, LT-10223 Vilnius, Lithuania

E-mail.simona.kildiene@vgtu.lt

cross $^{\text {ref }}$ http://dx.doi.org/10.5755/j01.ee.26.5.9571

\begin{abstract}
In recent years, different countries and communities started to rely on future studies for planning and management programming. With the emergence of diverse technologies each day, the importance of future studies has become clearer than ever before. Technology foresight is an integral part of decision and policy making at the top level of governance, especially in countries with governmental economics such as Iran which is one of such countries with complicated economic and governmental systems in many areas. For Iran as a developing country, one of the most important sections of technology foresight is planning and decision making on $R \& D$ project selection. The present study focuses on introducing a new line in this part of future studies in the country. To this end, a model is established and SWARA method is applied for evaluating the model. SWARA is a new effective MADM method for evaluating criteria at the top level of decision and policy making bodies. The most important part of this study is about identifying the importance of criteria and sub-criteria of the established model for $R \& D$ projects selection in Iran. This research proposes a general framework for starting a new horizon in research activities in Iran.
\end{abstract}

Keywords: Technology Foresight, R\&D projects, Policy Making, Multiple Criteria Decision Making (MCDM), Step-wise Weight Assessment Ratio Analysis (SWARA).

\section{Introduction}

Today's world is changing rapidly in different paths. These changes can be studied in four parts including: i) assumption, ii) equipment and method, iii) goal and objective, iv) concept. Each of them leads to increased uncertainties, complexity of problems, scale of issues, and pervasiveness of technology dependence that presents tremendous challenges, opportunities or threats, to the policy and decision maker (Park \& Son, 2006).

To face these challenges, an approach to replace the traditional planning should be taken that shows what will happen in the future, and the appropriate way to deal with it. Technology Foresight (TF) is one of the most powerful tools to meet such demands. TF is an approach for collectively exploring, anticipating and shaping the future (Cassingena Harper, 2013).

There are many definitions of TF. The definition of (Martin, 1995) however, has come to be used as the widely accepted one since 1995. "Technology Foresight is the process for bringing partnership scientists, engineers, industrialists, Government officials and others together to identify domains of strategic research and the emerging technologies likely to yield the greatest economic and social benefit and which in the long term will sustain industrial competitiveness" (Martin, 1995).
From the historical point of view, policy makers have been considering future systematically, especially after World War II. Japan and America were the first countries to use foresight as an instrument of policy making. In early 1970s, the Japanese used the Delphi method (developed by the American Institute of Rand) to make predictions in science and technology, and have continued to repeat it every five years ever since. Using Delphi method in systematic way led to achievements that were more than a simple technology prediction. It made a new paradigm called Technology Foresight, followed by similar efforts in France, The Netherlands, Germany and the UK in the late 1980s, which mainly focused on science and technology (S\&T). Basically, at first, South Korea, France and partly the UK oriented foresight projects in a more self-organized manner. The fast diffusion of foresight to smaller and developing countries can be seen in the late 1990s (Jemala, 2010).

In Europe, full-scale national exercises were performed in Hungary and the Czech Republic around the year 2000, while in Slovakia, Malta, Cyprus, Estonia, Poland, Romania and Bulgaria only partial foresight exercises, more about setting priorities, building capacities or re-structuralization of national $R \& D$ systems were conducted (Saritas et al., 2006). Some countries, such as the Czech Republic, Poland, Ukraine and Hungary, have also made efforts to promote foresight on the national 
level, and increasingly more and more governments recognize the need to plan their future results that can contribute to shaping national or regional long-term development (UNIDO, 2005).

Over the years, TF development occurred in five generations. Technology forecasting which was done by experts, was the main part of the first generation of technology foresight. Technology foresight was equal to pure technology forecasting and the accuracy of these forecasts showed the effectiveness of foresight process in this generation. The second generation of foresight involved the technology, market and industry. Academic actors together with industrial experts joined to study science and technology development. Focusing on market demand and taking-up of priorities and development of networks among industry/academia participants were the main features of second generation (Zhouying, 2011).

In addition to previous topics, social issues were added to third generation of foresight. Topics like facing the aging of population, agriculture and others were studied during this generation. The third generation did not only keep the pervious actors but also integrated social, economic and environmental actors with them. Third generation expand the culture of foresight and it wires up the NIS.

Fourth generation of foresight, distributed actors in innovation ecosystem and the same actors as third generation but widening scope for example to regional level. The object of this generation was self- organizing National Innovation System (NIS) link to concepts of industry ecosystem and open innovation. The last generation is a mix of foresight programs and exercises, also distributed across many sites but in combination with other elements of strategic decision making. Science and technology innovation systems are the main focus in this generation. So this generation involved various types of stockholders (Cassingena Harper, 2013).

It is roughly possible to divide Technology Foresight (TF) literature into two main groups: (1) literature on national and industry programs and (2) research on TF in firms (Boutellier et al., 2007; Schlossstein \& Park, 2006; Saritas et al., 2006; Blind et al., 1998).

Generally, technology foresight processes are as follows (Rappert, 1999; Lee et al., 2006; Lee et al., 2008):

- Getting a list of critical technologies, which can support several different areas of innovation;

- Identifying possible developments in science and technology using a consensus-drive consultation exercise, which may help meet social needs over the long run;

- A priority term setting process;

- Over the years, several methods have been used to develop foresight research. (Magruk, 2011), presented proper classification of foresight methods. The methods were placed in 10 main categories and include: 1 . Consultative, 2. Creative, 3. Prescriptive, 4. Multi-criteria, 5. Radar, 6. Simulation, 7. Diagnostic, 8. Analytical, 9. Survey 10. Strategic.

The most important output of using TF can be considered in the following general categories: policy recommendations, analyzing trends and driving forces, scenarios, research priorities settings, technologies, forecasting and roadmap technology (Butter et al., 2009).

In this paper, a new application for TF in identifying criteria for $R \& D$ research and $R \& D$ project selection will be introduced. In other words, this paper seeks to define a foresight process. This process helps to identify key criteria for $R \& D$ studies and then to consider the perspective in selecting $R \& D$ projects.

Technology foresight helps to refine $R \& D$ project selection in two main ways. First, it helps to establish the criteria for identifying trends, key technologies and projections of future pictures. Second, TF can be used to take proper future-oriented measures to decide which project should be selected among numerous existing alternatives.

One of the major challenges decision makers have to face when dealing with $R \& D$ management, is the $R \& D$ project evaluation problem. Multiple criteria measuring rewards, relevance to the organization's mission and objectives, strategic leverage potential, probability of technical and commercial success constitute the evaluation process (Eilat et al., 2013; Halouani et al., 2009). Selecting research and development (R\&D) project is a complicated decision-making process. For this purpose, some steps must be taken including a thorough search of the environment of the opportunities, the creation of project alternatives, and different stakeholders' qualitative and quantitative evaluation (Mohanti et al., 2005).

In the last quarter of the twentieth century, considerable efforts have been made by management scientists to create different quantitative and qualitative methods for R\&D management, with special emphasis on project management and applying multiple criteria method for priority setting (Kumar, 2004). During the last few decades, varieties of methods have been introduced to the problem of R\&D project evaluation (Eilat et al., 2008).

Regarding the current ever-increasing changes in the business environment, $R \& D$ has become a type of investment companies make for their future. Companies require useful tools that can assist in the optimum allocation of resource decisions (Meade \& Presley, 2002). Forward-looking hi-tech organizations around the world constantly engaged in implementing research and development (R\&D) capital investment projects (Mohanti et al., 2005).

R\&D project selection is a vital task. It is a complex decision-making process involving multiple steps, multiple groups of decision-makers, multiple choices, multiple and often-conflicting objectives, and future success uncertainty (Ghasemzadeh \& Archer, 2000). One of the most significant points in project evaluation is how suitable evaluation tool to be used in that particular type of project (Coldrick et al., 2005).

R\&D projects can be defined in three broad areas (Coldrick et al., 2005):

1. Basic research;

2. Applied research;

3. Experimental development. 


\section{Structure of R\&D Project Evaluation}

This study is organized based on Iran's status in technology. Although Iran is a developing country with high potential in high-tech industries like Nanotechnology and Biotechnology, the country has not been successful enough regarding strategic management of the fields.

Recently the importance of futures studies, especially the technology foresight, has been taken into consideration in top levels of decision and policy making compared to the past., In this regard, Amirkabir University of Technology (Tehran Polytechnic) has started to conduct research specialized into the subject.

Amirkabir University of Technology (Tehran Polytechnic) is the first university in Iran that is conducting research activities on technology foresight at professional level now, which can be extended to the other universities shortly after. In this major, this university has been active with full time Ph.D. students since 2012.
One of the important parts of technology foresight in Iran's current status is R\&D project selection. The main part of economics is still being managed by the government in Iran. However the allocated governmental budget is limited and making the best decision associated with the projects and the industries is a vital issue to be addressed.

Here, the main question is about this research and what authors considered to do. The main part of this research focuses on establishing an appropriate model for evaluating R\&D projects selection. But the important tip about that is which methodology is suitable to use for identifying and evaluating criteria.

In order to identify the appropriate criteria in the future, we need a complete TF process.

Then we can use MCDM to R\&D project selection. (As shown in Figure 1).

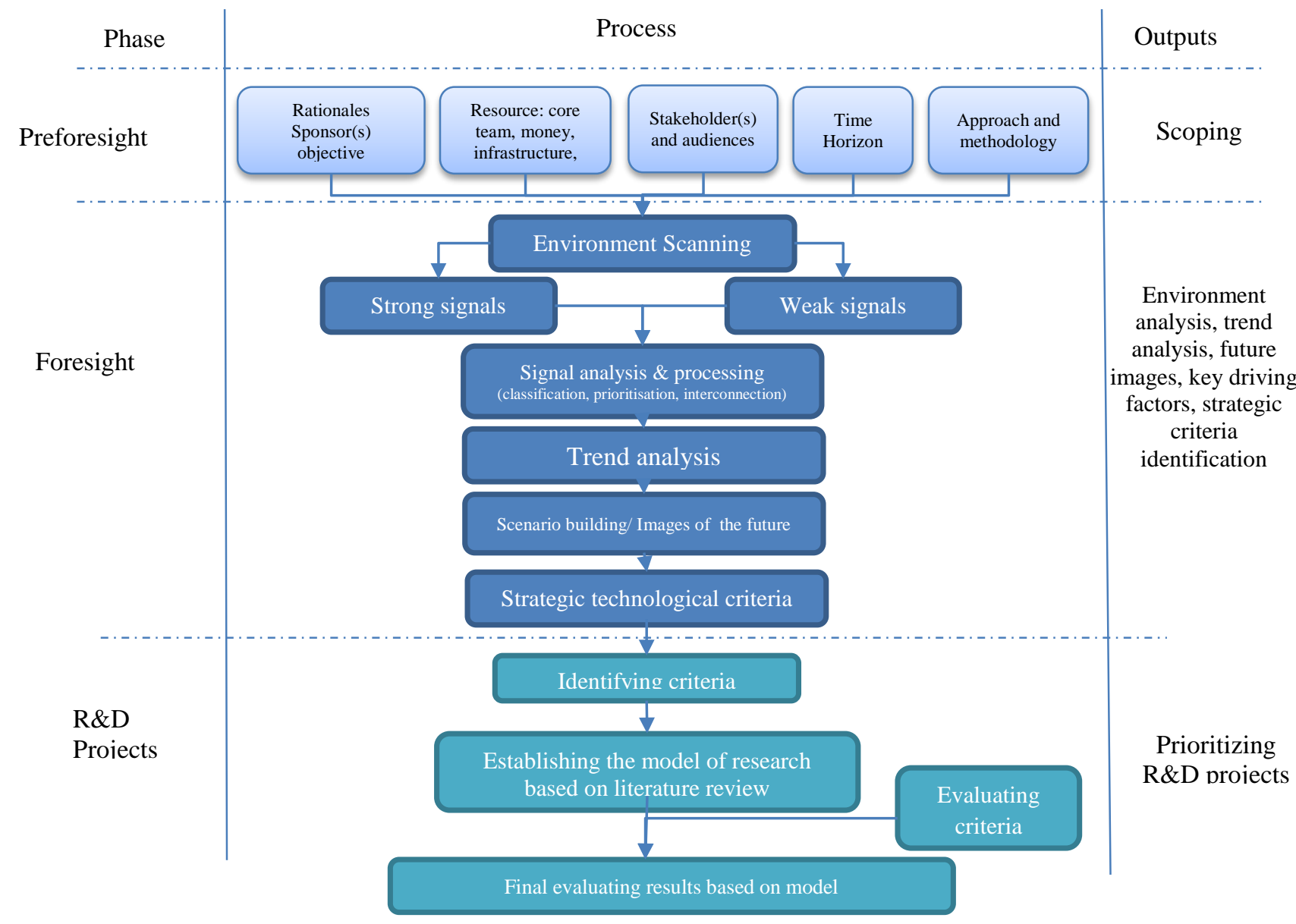

Figure 1. Framework of research

Determining the scope the TF project is the first step that must be taken. Deciding on what is expected to be achieved from Technology Foresight, who should be involved, what areas should be covered, what methods need to be used, etc. all of which are matters under debate and negotiation within a process we have called "scoping" (Keenan \& Miles, 2003).

TF phases began with environmental scanning and weak or strong signals detection. Classification and prioritizing the signals paved the way for identifying key factors that would shape the future. By analyzing trends, studying driving factor and determining key uncertainties, scenarios will be shaped. Analyzing scenarios will lead us to detect appropriate criteria in future.

After identifying the most important criteria, we can use MCDM techniques to select the projects. MCDM methods are useful tools to evaluate various criteria and alternatives in a decision making issue.

There are many methods for evaluating criteria such as AHP (Saaty, 1980), ANP (Saaty \& Vargas, 2001), FARE 
(Ginevicius, 2011) and SWARA (Kersuliene et al., 2010) which have been utilized in this study.

SWARA is a powerful method in top level of decision and policy making. The main advantage of this method in decision making is that: in some problems, priorities are defined based on policies of companies or countries and there is no need for evaluation to rank the criteria. In other methods like AHP or ANP, the models are created based on criteria, and experts' evaluations will affect priorities and ranks. So, SWARA can be best used when the priorities have already been set useful for some issues when the priorities have already been set according to different situations and now finally SWARA is proposed to be applied in a certain environment of decision making (Hashemkhani Zolfani \& Saparauskas, 2013). Therefore, authors believe that this methodology can be helpful in the process of effective decision and policy making as presented in this article. The process is shown in figure 2 .

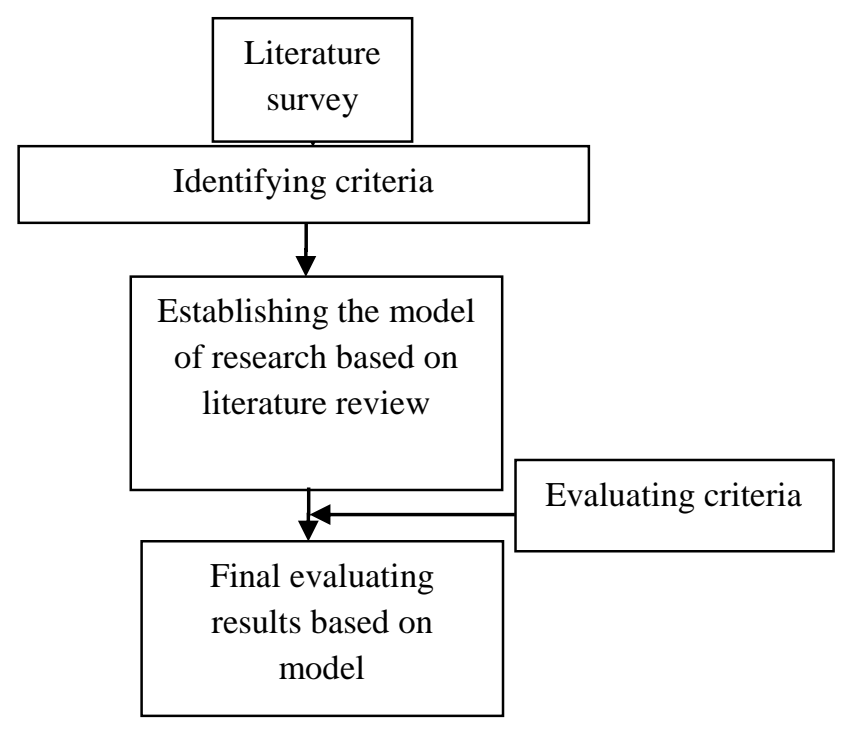

Figure 2. Framework of R\&D project selection phase

\section{Establishing model of research}

The important issue that should be considered in this part is levels and projects phases as follows:

- Basic phase: In this phase, knowledge relating to the technology is gathered. To get technical and marketing help in the future, the new product development is correlated with previous products., Various surveys are carried out in this phase and all necessary resources for the research are collected. It involves different laboratory studies, related process plans, an economic evaluation of different process plans, etc (Mohanti et al., 2005).

- Applied phase: In this phase, to develop technology and process plans in new product development, laboratory research is carried out. Economic evaluations of the new technology and feasibility studies are conducted in this phase (Mohanti et al., 2005).
- Development phase: This is the final phase of a $\mathrm{R} \& \mathrm{D}$ project. The technology established in the applied phase is utilized for the new product development. In this phase, some product manufacture issues like design, quality, and the procurement issues are considered (Mohanti et al., 2005).

This model of research is based on a thorough analysis of the previously known data, mainly in the basic and applied phase. In Iran, there is much greater emphasis put on this phase, since it is where the major problems usually occur. The model is relatively general because the country lacks a comprehensive plan in this field--this model would be suitable for meeting the initial challenge. However, we have tried to consider all the important criteria to make a suitable framework for decision making about R\&D projects selection. The considered criteria and sub-criteria for establishment of the model is presented in table 3 .

Table 3

The model of research

\begin{tabular}{|c|l|l|}
\hline & \multicolumn{1}{|c|}{ Criteria and Sub-Criteria } & \multicolumn{1}{|c|}{ Reference } \\
\hline $\mathrm{C}_{1}$ & Technological merit & \\
\hline $\mathrm{C}_{1-1}$ & Competitiveness of technology & (Huang et al., 2008) \\
\hline $\mathrm{C}_{1-2}$ & Social ambience & (Mohanti et al., 2005; Balachandra, 1997) \\
\hline $\mathrm{C}_{1-3}$ & Potential technical interaction with existing technology & $\begin{array}{l}\text { M(ohanti } \text { et al., 2005; Huang } \text { et al., 2008; Kumar, 2004; } \\
\text { Meade \& Presley, 2002) }\end{array}$ \\
\hline $\mathrm{C}_{2}$ & \multicolumn{1}{c|}{ Technical } & (Coldrick et al., 2005) \\
\hline $\mathrm{C}_{2-1}$ & Technical resource availability & (Kumar 2004; Balachandra, 1997) \\
\hline $\mathrm{C}_{2-2}$ & Anticipated Completion time & \\
\hline
\end{tabular}




\begin{tabular}{|c|c|c|}
\hline & Criteria and Sub-Criteria & Reference \\
\hline $\mathrm{C}_{2-3}$ & Attractiveness of technological route & (Kumar, 2004) \\
\hline $\mathrm{C}_{2-4}$ & Probability of technical success & (Meade \& Presley, 2002) \\
\hline $\mathrm{C}_{3}$ & Risk & \\
\hline $\mathrm{C}_{3-1}$ & Technical risk & (Mohanti et al. 2005; Huang et al., 2008) \\
\hline $\mathrm{C}_{3-2}$ & Commercial risk & $\begin{array}{l}\text { (Mohanti et al., 2005; Huang et al., 2008; Coldrick et al., } \\
\text { 2005) }\end{array}$ \\
\hline $\mathrm{C}_{3-3}$ & Economic risk & (Mohanti et al., 2005) \\
\hline $\mathrm{C}_{3-4}$ & Development risk & (Huang et al., 2008) \\
\hline $\mathrm{C}_{3-5}$ & Risk in obtaining regulatory clearance & (Coldrick et al., 2005) \\
\hline $\mathrm{C}_{4}$ & $\begin{array}{c}\text { Market } \\
\end{array}$ & \\
\hline $\mathrm{C}_{4-1}$ & The potential size of market & $\begin{array}{l}\text { (Meade \& Presley, 2002); Huang et al. (2008); Mohanti } \\
\text { et al. (2005) }\end{array}$ \\
\hline $\mathrm{C}_{4-2}$ & Expected market share & $\begin{array}{l}\text { (Huang et al., 2008; Mohanti et al., 2005; Coldrick et al., } \\
\text { 2005) }\end{array}$ \\
\hline $\mathrm{C}_{4-3}$ & Financial feasibility & (Kumar, 2004) \\
\hline $\mathrm{C}_{4-4}$ & Number and strength of competitors & (Meade \& Presley, 2002) \\
\hline $\mathrm{C}_{5}$ & $\begin{array}{r}\text { Regulation } \\
\end{array}$ & \\
\hline $\mathrm{C}_{5-1}$ & Government policy & (Mohanti et al., 2005) \\
\hline $\mathrm{C}_{5-2}$ & Economic regulation & (Mohanti et al., 2005) \\
\hline $\mathrm{C}_{5-3}$ & Environmental policy & (Mohanti et al., 2005) \\
\hline $\mathrm{C}_{5-4}$ & Ability to meet likely future regulations & (Coldrick et al., 2005) \\
\hline
\end{tabular}

\section{Step-wise Weight Assessment Ratio Analysis (SWARA)}

One of the latest methods among MADM methods, is called SWARA method that can be used instead of AHP, ANP and FARE methods. SWARA is introduced by (Kersuliene et al., 2010) and has undergone much development in recent years.

SWARA can be defined as an expert-oriented method as the experts' viewpoints is regarded as the most significant deciding factor in evaluations and calculating weights in the process of this method. In the next steps of this method, experts determine the value of each criterion and rank all the criteria from the first to the last one. Then, the importance of each criterion is calculated and all the criteria are ranked from the first to the last one (the most significant to the least significant) based on experts' implicit knowledge, information and experiences.

Based on the mediocre value of ranks, the overall ranks of the group of experts are determined (Kersuliene \& Turskis, 2011).

One of the influential and powerful attributes of SWARA method is its ability to estimate experts' opinion about importance ratio of the criteria in the process of their weight determination (Kersuliene et al., 2010), and it is a helpful way for experts' data collecting and data organizing. The experts can easily work together based on the simplicity of the aforementioned process (Hashemkhani Zolfani \& Zavadskas, 2013).

In case of some companies or countries' policies, priorities can be defined without any need to evaluate and rank the criteria which is another one of the indispensable attributes of SWARA method which sets it apart from other methods such as AHP and ANP. Since in the latter, experts' evaluations will affect the priorities, the ranks and the model is created based on criteria.

According to this analysis, it can be concluded that when the priorities are known based on the situation, SWARA is a practical method and is recommended to be applied in certain environments for decision making (Hashemkhani Zolfani \& Zavadskas, 2013). All the methods applied in the past, along with recent research with SWARA methodology are presented in the table below (Table 4).

\section{Recent research with SWARA methodology}

\begin{tabular}{|l|l|}
\hline \multicolumn{1}{|c|}{ Authors } & \multicolumn{1}{c|}{ Considered problem } \\
\hline (Kersuliene et al., 2010) & Rational dispute resolution method selection \\
\hline (Kersuliene \& Turskis, 2011) & Architect selection \\
\hline (Hashemkhani Zolfani et al., 2013a) & Product design \\
\hline (Hashemkhani Zolfani et al, 2013b) & $\begin{array}{l}\text { Selecting the optimal alternative of mechanical longitudinal ventilation of tunnel } \\
\text { pollutants }\end{array}$ \\
\hline (Hashemkhani Zolfani et al., 2013c) & Investigating on the success factors of online games based on explorer \\
\hline (Hashemkhani et al., 2013d) & Decision making on business issues with foresight perspective \\
\hline (Hashemkhani \& Zavadskas, 2013) & $\begin{array}{l}\text { Sustainable Development of Rural Areas' Building Structures Based on Local } \\
\text { Climate }\end{array}$ \\
\hline (Aghadie et al., 2013a) & The machine tool selection \\
\hline (Aghadie et al., 2013b) & Market segmentation and selection \\
\hline
\end{tabular}


Sarfaraz Hashemkhani Zolfani, Jalil Salimi, Reza Maknoon, Kildiene Simona. Technology Foresight About R\&D...

\begin{tabular}{|l|l|}
\hline \multicolumn{1}{|c|}{ Authors } & \multicolumn{1}{c|}{ Considered problem } \\
\hline (Alimardani et al., 2013) & Agile supplier selection \\
\hline (Hashemkhani Zolfani \& Saparauskas, 2013) & Prioritizing Sustainability Assessment Indicators of Energy System \\
\hline (Volvaciovas et al., 2013) & Selection of Public Buildings Retrofits Strategy \\
\hline (Zavadskas et al., 2013) & Ranking technique for alternatives of technology in construction \\
\hline (Aghdaie et al., 2014) & Supplier selection \\
\hline (Hashemkhani Zolfani \& Bahrami, 2014) & Investment Prioritizing in High Tech Industries \\
\hline (Vafaeipour et al., 2014) & Regions priority for implementation of solar projects \\
\hline (Ruzgys et al., 2014) & Evaluation of external wall insulation in residential buildings \\
\hline (Stanujkic et al., 2015) & Selection of a packaging design \\
\hline (Haghnazar Kouchaksaraei et al., 2015) & Glasshouse locating \\
\hline (Hashemkhani Zolfani et al., 2015) & Evaluation of strategies \\
\hline
\end{tabular}

The process of SWARA method is shown in figure. 3.

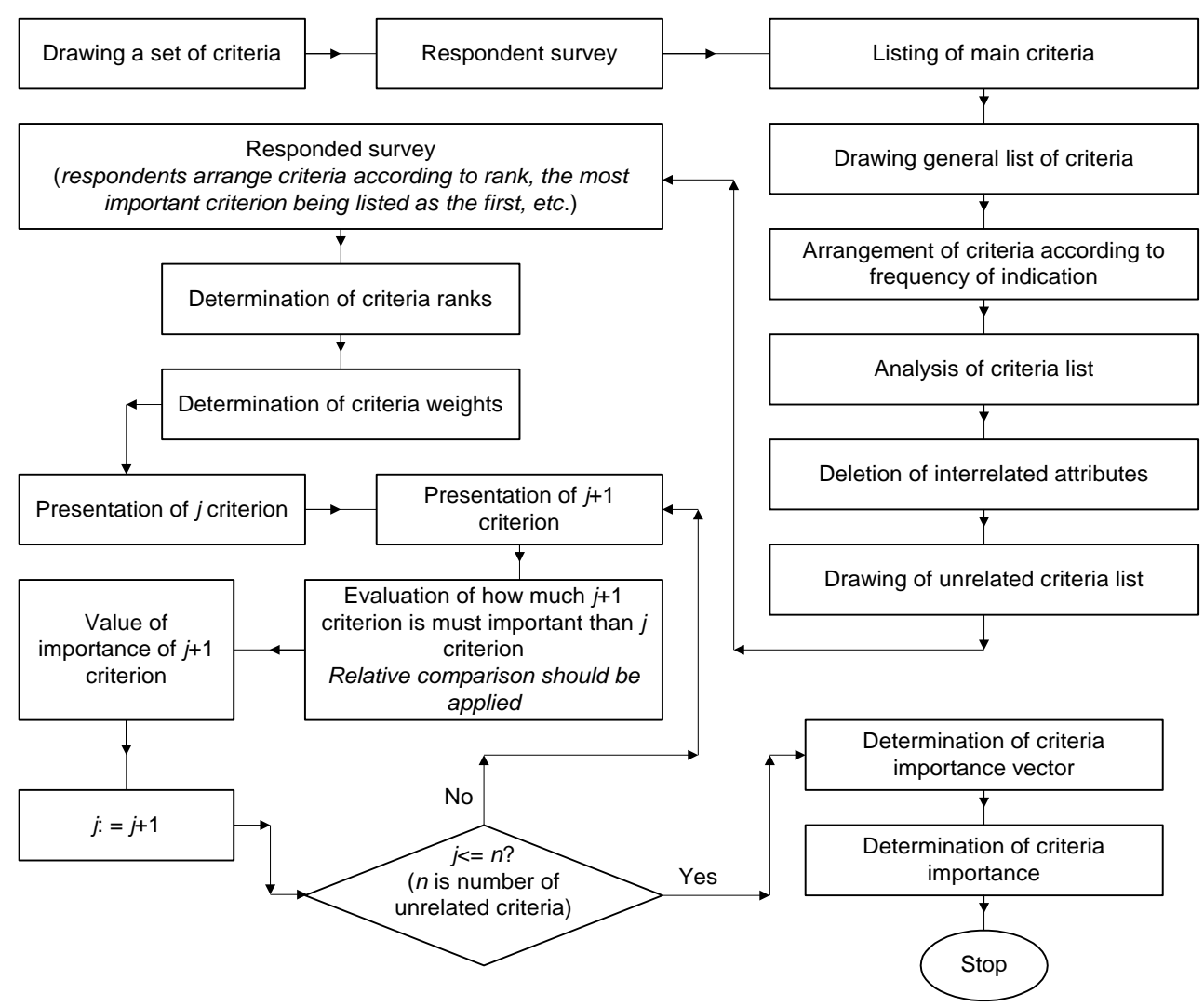

Figure 3. Determining of the criteria weights based on SWARA (Kersuliene \& Turskis, 2011)

\section{Experts' information}

This part is organized due to experts' ideas affecting the results. Experts from different fields have cooperated in this study.
The information about fields of experts are presented in table 2. All experts have experience more than 10 years in their relevant fields.

Table 5

Background information of participated experts in SWARA section

\begin{tabular}{|c|l|c|}
\hline \multicolumn{1}{|c|}{ Category } & \multicolumn{1}{c|}{ Classification } & \\
\hline \multirow{5}{*}{ Working in background } & High tech engineering & \\
\cline { 2 - 3 } & Industrial engineering & \\
\cline { 2 - 3 } & Finance & 1 \\
\cline { 2 - 3 } & Economic and social science & 1 \\
\cline { 2 - 3 } Education Level & Advocacy (Law) & 1 \\
\hline \multirow{2}{*}{ Sex } & Bachelor & \\
\cline { 2 - 3 } & Master & \\
\cline { 2 - 3 } & Ph.D. & 3 \\
\hline
\end{tabular}




\section{SWARA Results}

In the following section, the SWARA method is generally applied. At the first step, experts make decisions about priority of criteria. Five criteria are prioritized based on experts' ideas in table 6 . In tables 7-11, sub-criteria are evaluated and prioritized according to the experts comments, and finally in table 12 all of the final criteria's weights are presented. The final weights of sub-criteria are calculated based on the weights of criteria.

Table 6

Final results of weighting assessment criteria

\begin{tabular}{c|c|c|c|c}
\hline Criterion & $\begin{array}{c}\text { Comparative importance } \\
\text { of average value } s_{j}\end{array}$ & Coefficient $k_{j}=s_{j}+1$ & $\begin{array}{c}\text { Recalculated weight } \\
w_{j}=\frac{x_{j-1}}{k_{j}}\end{array}$ & $\begin{array}{l}\text { Weight } \\
q_{j}=\frac{w_{j}}{\sum w_{j}}\end{array}$ \\
\hline $\mathrm{C}_{1}$ & & 1 & 1 & 0,2658 \\
\hline $\mathrm{C}_{4}$ & 0,1584 & 1,1584 & 0,8633 & 0,2295 \\
\hline $\mathrm{C}_{2}$ & 0,1834 & 1,1834 & 0,7295 & 0,1939 \\
\hline $\mathrm{C}_{3}$ & 0,1584 & 1,1584 & 0,6297 & 0,1674 \\
\hline $\mathrm{C}_{5}$ & 0,1667 & 1,1667 & 0,5397 & 0,1435 \\
\hline
\end{tabular}

Table 7

Final results of weighting criteria of technological merit

\begin{tabular}{|c|c|c|c|c|}
\hline Criterion & $\begin{array}{c}\text { Comparative importance } \\
\text { of average value } S_{j}\end{array}$ & Coefficient $k_{j}=s_{j}+1$ & $\begin{array}{l}\text { Recalculated weight } \\
\qquad w_{j}=\frac{x_{j-1}}{k_{j}}\end{array}$ & Weight $q_{j}=\frac{w_{j}}{\sum w_{j}}$ \\
\hline $\mathrm{C}_{1-2}$ & & 1 & 1 & 0,3818 \\
\hline $\mathrm{C}_{1-1}$ & 0,175 & 1,175 & 0,8511 & 0,325 \\
\hline $\mathrm{C}_{1-3}$ & 0,1083 & 1,1083 & 0,7679 & 0,2932 \\
\hline
\end{tabular}

Table 8

Final results of weighting criteria of market

\begin{tabular}{c|c|c|c|c}
\hline Criterion & $\begin{array}{c}\text { Comparative importance } \\
\text { of average value } s_{j}\end{array}$ & $\begin{array}{c}\text { Recalculated weight } \\
\text { Coefficient } k_{j}=s_{j}+1\end{array}$ & $\begin{array}{c}x_{j-1} \\
k_{j}\end{array}$ \\
\hline $\mathrm{C}_{4-3}$ & & 1 & 1 \\
\hline $\mathrm{C}_{4-4}$ & 0,15 & 1,15 & 0,8698 \\
\hline $\mathrm{C}_{4-1}$ & 0,1667 & 1,1667 & 0,3060 \\
\hline $\mathrm{C}_{4-2}$ & 0,1417 & 1,1417 & 0,2661 \\
\hline
\end{tabular}

Table 9

Final results of weighting criteria of technical

\begin{tabular}{c|c|c|c|c}
\hline Criterion & $\begin{array}{c}\text { Comparative importance } \\
\text { of average value } s_{j}\end{array}$ & $\begin{array}{c}\text { Coefficient } \\
k_{j}=s_{j}+\mathbf{1}\end{array}$ & $\begin{array}{c}\text { Recalculated weight } \\
\boldsymbol{w}_{j}=\frac{\boldsymbol{x}_{j-1}}{\boldsymbol{k}_{j}}\end{array}$ & $\begin{array}{c}\text { Weight } \\
q_{j}=\frac{w_{j}}{\sum w_{j}}\end{array}$ \\
\hline $\mathrm{C}_{2-2}$ & & 1 & 1 & 0,3184 \\
\hline $\mathrm{C}_{2-1}$ & 0,2 & 1,2 & 0,8333 & 0,2653 \\
\hline $\mathrm{C}_{2-4}$ & 0,1834 & 1,1834 & 0,7042 & 0,2242 \\
\hline $\mathrm{C}_{2-3}$ & 0,1667 & 1,1667 & 0,6036 & 0,1922 \\
\hline
\end{tabular}

Table 10

Final results of weighting criteria of risk

\begin{tabular}{c|c|c|c|c}
\hline Criterion & $\begin{array}{c}\text { Comparative importance } \\
\text { of average value } s_{j}\end{array}$ & $\begin{array}{c}\text { Recalculated weight } \\
k_{j}=s_{j}+1\end{array}$ & $\begin{array}{c}x_{j-1} \\
k_{j}\end{array}$ \\
\hline $\mathrm{X}_{3-5}$ & 1 & 1 & $w_{j}$ \\
\hline $\mathrm{X}_{3-3}$ & 0,1417 & 1,1417 & 0,8759 \\
\hline $\mathrm{X}_{3-2}$ & 0,1583 & 1,1583 & 0,7562 \\
\hline $\mathrm{X}_{3-1}$ & 0,1417 & 1,1417 & 0,6623 \\
\hline $\mathrm{X}_{3-4}$ & 0,1667 & 1,1667 & 0,2589 \\
\hline
\end{tabular}


Sarfaraz Hashemkhani Zolfani, Jalil Salimi, Reza Maknoon, Kildiene Simona. Technology Foresight About R\&D...

Table 11

Final results of weighting criteria of regulation

\begin{tabular}{c|c|c|c|c}
\hline Criterion & $\begin{array}{c}\text { Comparative importance } \\
\text { of average value } S_{j}\end{array}$ & $\begin{array}{c}\text { Coefficient } \\
k_{j}=s_{j}+\mathbf{1}\end{array}$ & $\begin{array}{c}\text { Recalculated weight } \\
\boldsymbol{w}_{j}=\frac{\boldsymbol{x}_{j-1}}{\boldsymbol{k}_{j}}\end{array}$ & $\begin{array}{c}\text { Weight } \\
\boldsymbol{q}_{j}=\frac{\boldsymbol{w}_{j}}{\sum \boldsymbol{w}_{j}}\end{array}$ \\
\hline $\mathrm{X}_{5-1}$ & & 1 & 1 & 0,3121 \\
\hline $\mathrm{X}_{5-3}$ & 0,1833 & 1,1833 & 0,8451 & 0,2637 \\
\hline $\mathrm{X}_{5-2}$ & 0,1583 & 1,1583 & 0,7296 & 0,2277 \\
\hline $\mathrm{X}_{5-4}$ & 0,1583 & 1,1583 & 0,6299 & 0,1966 \\
\hline
\end{tabular}

The final weights of sub-criteria are calculated and presented in table 12.

Table 12

Final weights table

\begin{tabular}{|c|c|c|}
\hline & Criteria and Sub-Criteria & Relative weights \\
\hline $\mathrm{C}_{1}$ & Technological merit & 0,2658 \\
\hline $\mathrm{C}_{1-1}$ & Competitiveness of technology & 0,0864 \\
\hline $\mathrm{C}_{1-2}$ & Social ambience & 0,1015 \\
\hline $\mathrm{C}_{1-3}$ & Potential technical interaction with existing technology & 0,0779 \\
\hline $\mathrm{C}_{2}$ & Technical & $\mathbf{0 , 1 9 3 9}$ \\
\hline $\mathrm{C}_{2-1}$ & Technical resource availability & 0,0514 \\
\hline $\mathrm{C}_{2-2}$ & Anticipated Completion time & 0,0617 \\
\hline $\mathrm{C}_{2-3}$ & Attractiveness of technological route & 0,0373 \\
\hline $\mathrm{C}_{2-4}$ & Probability of technical success & 0,0435 \\
\hline $\mathrm{C}_{3}$ & Risk & 0,1674 \\
\hline $\mathrm{C}_{3-1}$ & Technical risk & 0,0287 \\
\hline $\mathrm{C}_{3-2}$ & Commercial risk & 0,0328 \\
\hline $\mathrm{C}_{3-3}$ & Economic risk & 0,038 \\
\hline $\mathrm{C}_{3-4}$ & Development risk & 0,0246 \\
\hline $\mathrm{C}_{3-5}$ & Risk in obtaining regulatory clearance & 0,0433 \\
\hline $\mathrm{C}_{4}$ & Market & 0,2295 \\
\hline $\mathrm{C}_{4-1}$ & The potential size of market & 0,0523 \\
\hline $\mathrm{C}_{4-2}$ & Expected market share & 0,0458 \\
\hline $\mathrm{C}_{4-3}$ & Financial feasibility & 0,0702 \\
\hline $\mathrm{C}_{4-4}$ & Number and strength of competitors & 0,0611 \\
\hline $\mathrm{C}_{5}$ & Regulation & $\mathbf{0 , 1 4 3 5}$ \\
\hline $\mathrm{C}_{5-1}$ & Government policy & 0,0448 \\
\hline $\mathrm{C}_{5-2}$ & Economic regulation & 0,0327 \\
\hline $\mathrm{C}_{5-3}$ & Environmental policy & 0,0378 \\
\hline $\mathrm{C}_{5-4}$ & Ability to meet likely future regulations & 0,0282 \\
\hline
\end{tabular}

All of the information related to the weights of criteria and sub-criteria are presented in table 6-11.

The general finding indicates that the technological merit is the most important criterion and market, technical, risk and regulation rank after that respectively.

\section{Conclusion}

Nowadays, the importance of future studies and technology foresight has become evident issue for various industries and countries. The R\&D projects and making appropriate decision about them is one of the significant parts of technology foresight. Iran is a developing country with high development potential in high-tech technologies and industries.
This research concentrated on $R \& D$ projects selection from the technology foresight perspective. The presented model is established based on criteria found in the literature and considering their localization according to Iran's situation.

A top level decision making tool, SWARA, is applied for evaluating the identified criteria for the purpose of prioritization. Undoubtedly, results of this research can be useful for making better decisions on the future of technologies and the relevant investments in Iran.

The present study can be considered as a promising start for future scientific studies about technology foresight and $\mathrm{R} \& \mathrm{D}$ projects evaluation and selection.

\section{References}

Aghdaie, M. H., Hashemkhani Zolfani, S., \& Zavadskas, E. K. (2013a). Decision making in machine tool selection: An integrated approach with SWARA and COPRAS-G methods. Inzinerine Ekonomika-Engineering Economics, 24(1), 5-17.

Aghdaie, M. H., Hashemkhani Zolfani, S., \& Zavadskas, E. K. (2013b). A Hybrid Approach for Market Segmentation and Market Segment Evaluation and Selection: An Integration of Data Mining and MADM. Transformations in Business \& Economics, 12(2B)(29B), 431-458. 
Aghdaie, M. H., Hashemkhani Zolfani, S., \& Zavadskas, E. K. (2014). Synergies of data mining and multiple attribute decision making. Procedia - Social and Behavioral Sciences, 110, 767-776. http://dx.doi.org/10.1016/ j.sbspro.2013.12.921

Alimardani, M., Hashemkhani Zolfani, S., Aghdaie, M. \& Tamosaitiene, J. (2013). A novel hybrid SWARA and VIKOR methodology for Supplier selection in an agile environment. Technological and Economic Development of Economy, 19(3), 533-548. http://dx.doi.org/10.3846/20294913.2013.814606

Balachandra, R., \& Friar, J. H. (1997). Factors for Success in R\&D Projects and New Product Innovation: A Contextual Framework. IEEE Transactions on Engineering Management, 44(3), 276-287. http://dx.doi.org/10.1109/17.618169

Blind, K., Cuhls, K., \& Grupp, H. (1998). Current Foresight Activities in Central Europe. Technological Forecasting and Social Change, 60, 15-35. http://dx.doi.org/10.1016/S0040-1625(98)00021-3

Boutellier, R., Deplazes, U., \& Loffler, K. (2007). Model of Technology Foresight: An innovative Approach. IEEE International Engineering Management Conference, USA, 7-14. http://dx.doi.org/10.1109/iemc.2007.5235062

Butter, M., Brandes, F., Keenan, M., Popper, R., Giesecke, S., Rijkers-Defrasne, S., \& Crehan, P. (2009). Monitoring foresight activities in Europe and the rest of the world. Final Report of the European Foresight Monitoring Network EFMN. EUR, 24043.

Cassingena Harper, J. (2013). Impact of Technology Foresight: Nesta Working Paper, JEL Classification: O38, available at: www.nesta.org.uk/wp13-16.

Coldrick, S., Longhurst, P., Ivey, P., \& Hannis, J. (2005). An R\&D options selection model for investment decisions. Technovation, 25, 185-193. http://dx.doi.org/10.1016/S0166-4972(03)00099-3

Eilat, H., Golany, B., \& Shtub, A. (2008). R\&D project evaluation: An integrated DEA and balanced scorecard approach. Omega, 36, 895-912. http://dx.doi.org/10.1016/j.omega.2006.05.002

Ginevicius, R. (2011). A new determining method for the criteria weights in multi-criteria evaluation. International Journal of Information Technology \& Decision Making, 10(6), 1067-1095. http://dx.doi.org/10.1142/ S021962 2011004713

Ghasemzadeh, F., \& Archer, N. P. (2000). Project portfolio selection through decision support. Decision Support Systems, 29, 73-88. http://dx.doi.org/10.1016/S0167-9236(00)00065-8

Halouani, N., Chabchoub, H., \& Martel, J. M. (2009). PROMETHEE-MD-2T method for project selection. European Journal of Operational Research, 195(3), 841-849. http://dx.doi.org/10.1016/j.ejor.2007.11.016

Haghnazar Kouchaksaraei R, Hashemkhani Zolfani S, \& Golabchi M. (2015). Glasshouse locating based on SWARACOPRAS approach. International Journal of Strategic Property Management, 19(2):111-122. http://dx.doi.org/10. 3846/1648715X.2015.1004565

Hashemkhani Zolfani, S., Zavadskas, E. K., \& Turskis, Z. (2013a). Design of products with both International and Local perspectives based on Yin-Yang balance theory and SWARA method. Economska Istrazivanja-Economic Research, 26(2), 153-166.

Hashemkhani Zolfani, S., Aghdaie, M. H., Derakhti, A., Zavadskas, E. K., \& Morshed Varzandeh, M. H. (2013d). Decision making on business issues with foresight perspective; an application of new hybrid MCDM model in shopping mall locating. Expert Systems with Applications, 40, 7111-7121. http://dx.doi.org/10.1016/ j.eswa. 2013.06.040

Hashemkhani Zolfani, S., Esfahani, M. H., Bitarafan, M., Zavadskas, E. K., \& Lale Arefi, S. (2013b). Developing a new hybrid MCDM method for selection of the optimal alternative of mechanical longitudinal ventilation of tunnel pollutants during automobile accidents. Transport, 28(1), 89-96.

Hashemkhani Zolfani, S., Farrokhzad, M., \& Turskis, Z. (2013c). Investigating on successful factors of online games based on explorer. E\&M: Ekonomie a Management, 16(2), 161-169.

Hashemkhani Zolfani, S., \& Saparauskas, J. (2013). New Application of SWARA Method in Prioritizing Sustainability Assessment Indicators of Energy System. Inzinerine Ekonomika-Engineering Economics, 24(5) 408-414. http://dx.doi.org/10.1016/j.proeng.2013.04.163

Hashemkhani Zolfani, S., \& Zavadskas, E. K. (2013). Sustainable Development of Rural Areas’ Building Structures Based on Local Climate. Procedia Engineering, 57, 1295-1301. http://dx.doi.org/10.3846/20294913.2014.881435

Hashemkhani Zolfani, S., \& Bahrami, M. (2014). Investment Prioritizing in High Tech Industries Based on SWARACOPRAS approach. Technological and Economic Development of Economy, 20(3), 534-553. http://dx.doi.org/10.3846/16111699.2014.967715

Hashemkhani Zolfani S, Maknoon R, \& Zavadskas E. K. (2015). Multiple Nash equilibriums and evaluation of strategies; new application of MCDM methods. Journal of Business Economics and Management, 16(2): 290-306.

Huang, C. C., Chu, P. Y., \& Chiang, Y. H. (2008). A fuzzy AHP application in government-sponsored R\&D project selection. Omega, 36, 1038-1052. http://dx.doi.org/10.1016/j.omega.2006.05.003 
Sarfaraz Hashemkhani Zolfani, Jalil Salimi, Reza Maknoon, Kildiene Simona. Technology Foresight About R\&D...

Jemala, M. (2010). Evolution of foresight in the global historical context, Foresight, 12(4), 65-81. http://dx.doi.org/10. $1108 / 14636681011063004$

Keenan, M., \& Miles, I. (2003). Introducing a Strategic Framework for Scoping Technology Foresight: PREST, University of Manchester, UK.

Kersuliene, V., \& Turskis, Z. (2011). Integrated fuzzy multiple criteria decision making model for architect selection. Technological and Economic Development of Economy, 17(4), 645-666. http://dx.doi.org/10.3846/20294913. 2011. 635718

Kersuliene, V., Zavadskas, E. K., \& Turskis, Z. (2010). Selection of rational dispute resolution method by applying new step-wise weight assessment ratio analysis (SWARA). Journal of Business Economics and Management, 11(2), 243258. http://dx.doi.org/10.3846/jbem.2010.12

Kumar, S. S. (2004). AHP-based formal system for R\&D project evaluation. Journal of Scientific \& Industrial Research, Vol 63, 888-896.

Lee, H., Lee, C., Seol, H., \& Park, Y. (2006). On the R\&D Priority Setting in Technology Foresight: a DEA and ANP Approach. IEEE International Conference on Management of Innovation and Technology, Singapore, $1015-1019$. http://dx.doi.org/10.1109/icmit.2006.262375

Lee, H., Lee, C., Seol, H., \& Park, Y. (2008). On the R\&D priority setting in technology foresight: A DEA and ANP approach. International Journal of Innovation and Technology Management, 5(2), 201-219.

Magruk, A. (2011). Innovation classification of technology foresight methods. Technological and Economic Development of Economy, 17(4), 700-715. http://dx.doi.org/10.3846/20294913.2011.649912

Martin, B. (1995). A review of recent overseas programmes. HM Stationery Office.

Meade, L. M., \& Presley, A. (2002). R\&D Project Selection Using the Analytic Network Process. IEEE Transactions on Engineering Management, 9(1), 59-66. http://dx.doi.org/10.1109/17.985748

Mohanti, R. P., Agarwal, R., Choudhury, A. K., \& Tiwari, M. K. (2005). A fuzzy ANP-based approach to R\&D project selection: a case study. International Journal of Production Research, 43(24), 5199-5216. http://dx.doi.org/10. 1080/00207540500219031

Park, B., \& Son, S. H. (2006). Korean Technology Foresight for Science and Technology Policy Making. Second International Seville Seminar on Future-Oriented Technology Analysis: Impact of FTA Approaches on Policy and Decision-Making - Seville, 28-29.

Rappert, B. (1999). "Rationalising future? Foresight in science and technology policy co-ordination," Futures, 31, 527545. http://dx.doi.org/10.1016/S0016-3287(99)00012-9

Ruzgys, A.; Volvaciovas, R.; Ignatavicius, C.; \& Turskis, Z. 2014. Integrated evaluation of external wall insulation in residential buildings using SWARA-TODIM MCDM method. Journal of Civil Engineering and Management, 20(1), 103-110. http://dx.doi.org/10.3846/13923730.2013.843585

Saaty, L. T. (1980). The Analytic Hierarchy Process. McGraw Hill Company, New York.

Saaty, L. T., \& Vargas, L. G. (2001). Models, Methods, Concepts \& Applications of the Analytical Hierarchy Process. Kluwer Academic Publishers, Boston. http://dx.doi.org/10.1007/978-1-4615-1665-1

Saritas, O. (2006). "Systems thinking for foresight', thesis, PREST, University of Manchester, Manchester, p. 11.

Saritas, O., Taymaz, E., \& Turner, T. (2006). "Vision 2023: Turkey's national Technology Foresight Program: A contextualist analysis and discussion". Technological Forecasting \& Social Change, 74, 1374-1393. http://dx.doi.org/10.1016/j.techfore.2006.07.005

Schlossstein, D., \& Park, B. (2006). "Comparing recent technology foresight studies in Korea and China: towards foresight-minded governments?" Foresight, 8(6), 48-70. http://dx.doi.org/10.1108/14636680610712531

Stanujkic, D, Karabasevic, D, \& Zavadskas, E. K. (2015). A framework for the Selection of a packaging design based on the SWARA method. Inzinerine Ekonomika-Engineering Economics, 26(2), 181-187.

UNIDO (2005). Technology Foresight Manual. Volumes 1 and 2, CD, UNIDO, Vienna.

Vafaeipour, M., Hashemkhani Zolfani, S., Varzandeh, M. H. M., Derakhtic, A., \& Eshkalagd, M. K. (2014). Assessment of regions priority for implementation of solar projects in Iran: New application of a hybrid multi-criteria decision making approach, Energy Conversion and Management, 86, 653-663.

Volvaciovas, R., Turskis, Z., Aviza, D., \& Mikstiene, R. 2013. Multi-attribute Selection of Public Buildings Retrofits Strategy, 11th International Scientific Conference on Modern Building Materials, Structures and Techniques MAY 16-17, 2013. Procedia Engineering, 57, 1236-1241. http://dx.doi.org/10.1016/j.enconman.2014.05.083

Zavadskas, E. K., Turskis, Z., Volvaciovas, R., \& Kildiene, S. 2013. Multi-criteria Assessment Model of Technologies. Studies in Informatics and Control, 22(4), 249-258.

The article has been reviewed.

Received in January, 2015; accepted in December, 2015. 